\title{
Analyzing Physico - Chemical Quality Parameters of Abay River Near To Bahir Dar, Ethiopia
}

\author{
Teka Girmay Hishe ${ }^{1^{*}} \quad$ Afera Halefom Teka ${ }^{1} \quad$ Asrat Teshome $^{1} \quad$ Ketema Feye Ayane ${ }^{1}$ \\ Birhane Shimondi Birhane ${ }^{2}$ \\ 1.Hydraulic and Water Resources Department, Faculty of Technology, Debre Tabor University, Debre Tabor, \\ Ethiopia \\ 2.Department of water supply and Sanitary Engineering, Dimma water supply office, Gambella, Ethiopia
}

\begin{abstract}
Abay River is an important source of domestic and drinking water in Bahir Dar; Ethiopia. To analyze the quality of this river water samples were collected from various points of the river and tested at the dry season for different physicochemical quality parameters. In addition, samples were taken from point sources such as industrial waste and urban sewage to evaluate their impact on the river. The study was conducted at Bahir Dar, Ethiopia from kebele 11 to Sebatamit 17. The study involved assessing surface water physical and chemical parameters at 12 different points upstream, downstream and at mixing sites. Multi Probe and laboratory analysis were used to measure the physical-chemical characteristics of the Abay River. Water temperature, dissolved oxygen, total dissolved solids, electrical conductivity, salinity and $\mathrm{pH}$ were measured by a multi meter probe onsite. Whereas the other parameters such as turbidity, Biological oxygen demand, chemical oxygen demand and ammonia was measured using laboratory. Water Temperature $\left(22.2\right.$ to $\left.25.5^{\circ} \mathrm{C}\right)$, Total Dissolved Solids $(117$ to $753 \mathrm{mg} / \mathrm{l})$, Turbidity (12.72 to $240 \mathrm{NTU}$ ), Dissolved Oxygen (2.5 to $7.8 \mathrm{mg} / \mathrm{l}$ ), $\mathrm{pH}$ (6.5 to 7.96), Electric Conductivity (180 to $1158 \mu \mathrm{S} / \mathrm{cm}$ ), Salinity $(0.11$ to $1.5 \mathrm{mg} / \mathrm{l})$,Bio-chemical Oxygen Demand (5.3 to $50 \mathrm{mg} / \mathrm{l})$, Chemical Oxygen Demand $(16$ to $151 \mathrm{mg} / \mathrm{l})$ and ammonia $(0.012$ to $56 \mathrm{mg} / \mathrm{l})$. Based on the findings the most parameters were above the permissible limit of world health organization and the water was unfit for drinking purpose without treatment. Keywords: Physico-chemical, Abay River, pollution, water quality, Ethiopia
\end{abstract}

DOI: $10.7176 / \mathrm{CER} / 12-2-02$

Publication date: February $29^{\text {th }} 2020$

\section{INTRODUCTION}

Clean water is very important for all forms of life to survive. Although water covers three fourth part of the earth's surface, getting of freshwater has become a serious problem in the world. Due to the quality of water deterioration due to different factors result from human development. The major once is the expansion of industrialization and the rapid growth of the world population. The amount of heavy rain that results in high runoff from the agricultural land, lack of soil and water conservation system management also affects the quality of water bodies. As a result, many perpetual rivers become short-lived and even dried out(Thillai Arasu, Hema et al. 2007). Massive physical, chemical and biological interactions result in water quality characteristics of aquatic ecosystems. The water bodies such as rivers and lakes are continuously experiencing a dynamic change in their geological age and geochemical characteristics(Sahoo 2014). This complex equilibrium in the aquatic ecosystem is disrupted by human activities resulting in pollution, which in turn manifests dramatically as fish kill, the bad taste of drinking water, and unregulated aquatic weed growth(Fan, Wang et al. 2012).

Quality of water is now a great concern for people of all parts of the world. There are different sources of pollutants that could damage the quality of water resources(Haider, Al et al. 2016). Similarly, there is no such environmental protection practice in Ethiopia, particularly in Bahir Dar City, as there are a number of polluting sources that have continuously deteriorated the quality of surface water.

The following hazard centers were considered as major categories of pollutant sources in the study area based on information obtained, observations made during site visits and analytical results. These include industrial establishment, agriculture, municipal waste, fuel stations, garages, car washing, hotels, homes, and health centers (Ayalew and 2014).

These bodies of surface water are the source for disposal of industrial effluent and household waste. As a result, the natural dynamic equilibrium between the environmental segments is disturbed leading to the condition of polluted rivers(Mahananda, Mohanty et al. 2010). Food for consumers should be free of pathogenic organisms and harmful substances(Thillai Arasu, Hema et al. 2007), according to the decision of the World Health Organization (WHO). Ethiopia faces persistent problems of floods and droughts and high contamination of aquatic resources, despite large water resources in lakes and rivers(Tamiru, Dagnachew et al. 2004). River Abay is also one of the water resources that have been affected by point sources effluent generated by textile(Mehari, Gebremedhin et al. 2015), tannery(Ayalew and 2014) and municipal (Mehari, Gebremedhin et al. 2016) wastewater sources. As a result, there will be a high concentration of nutrients that enhance the growth of floating plants such as hyacinth(Stålnacke, Grimvall et al. 2003).the higher growth of such plants reduce the amount of 
dissolved oxygen inside the river(Haider, $\mathrm{Al}$ et al. 2016). This reduction of the amount of dissolved oxygen will affect the life of aquatic life such as fish(Miller 2005, Dudgeon, Arthington et al. 2006) that cannot survive below $4 \mathrm{mg} / \mathrm{l}$ amount of oxygen(Mehari, Gebremedhin et al. 2016). The present study analyzed various parameters (Water Temperature, Total Suspended Solids (TSS), Total Dissolved Solids (TDS), Total Dissolved Solids (TS), Turbidity, Dissolved Oxygen (DO), Biochemical Oxygen Demand (BOD), Chemical Oxygen Demand (COD), pH, Electrical Conductivity (EC), Salinity and Chloride content) of water samples from twelve sites which are very important in assessing water quality.

\section{MATERIAL AND METHODS}

\subsection{Study area}

In the Amhara region Ethiopia, the Abay river is situated between latitude $11^{\circ} 8^{\prime} \mathrm{N}$ and longitudes $39^{\circ} 38^{\prime} \mathrm{E}$. After it joins different tributaries it becomes Blue Nile River that flows from Ethiopia to Egypt and Sudan. It originates from Gish Abay, Sekela woreda, west Gojam zone. For Ethiopia, Sudan and Egypt, the Abay River is very important. For Bahir Dar people, Ethiopia particularly it is used for several purposes such as domestic and agricultural purposes. Even though Bahir dar city is a very beautiful place as you have observed from the above definition the wastewater generated from this beautiful city and industries effluent become a risk for Abay river and lake tana. To alleviate such problems effective water quality is required by appropriate measurements for the water quality that can be described by Physico-chemical and microbiological characteristics (Akkaraboyina and Raju 2012),(Mahananda, Mahananda et al. 2005).

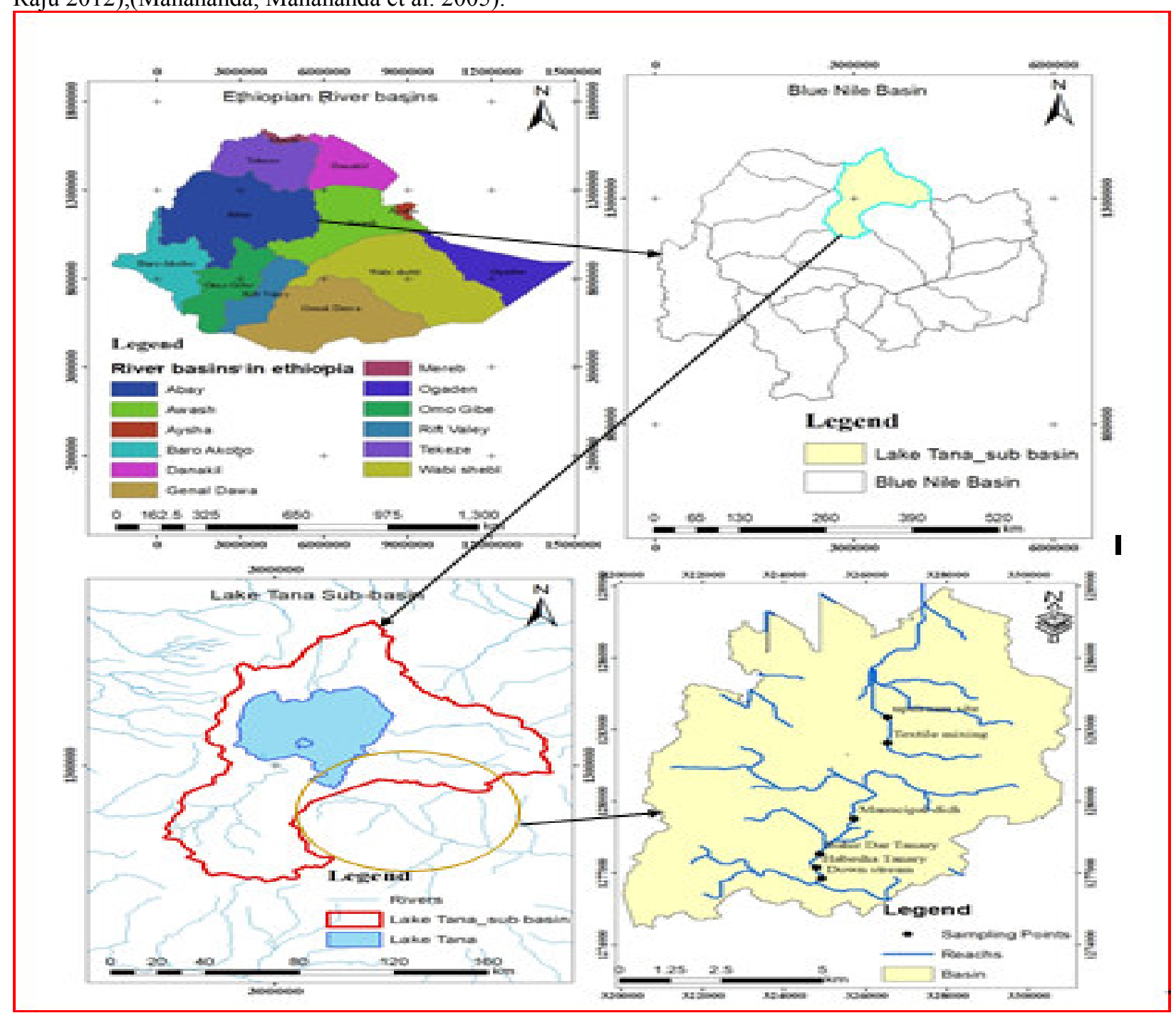

Figure 2 Location map of Study Area

\subsection{Sampling sites}

Water samples from the river mouth, middle and mouth of the river was taken. Sampling stations at four sources of wastewater effluent that contributes to the river water pollution where considered. 12 sampling stations (4 from 
a mixing point of effluent from the point sources such as textile, municipal ditch and tanneries, 4 upstream parts of the mixing points and the other 4 are after mixing sites) were chosen as shown on table 2.

Table 1 Water Quality Sampling Station of Abay River

\begin{tabular}{|c|c|c|}
\hline $\begin{array}{l}\text { Station } \\
\text { Number }\end{array}$ & Location of sampling points & Description \\
\hline 1 & Upstream of the river & Reference point near \\
\hline 2 & At mixing of Bahirdar textile effluent & At Textile effluent mixed mix the river \\
\hline 3 & After mixing & $200 \mathrm{~m}$ after mixing \\
\hline 4 & Upstream of municipal source & A reference point for municipal mix impact \\
\hline 5 & At mixing of municipal waste effluent & Municipal wastewater effluent mix with the river \\
\hline 6 & After mixing & $100 \mathrm{~m}$ after mixing \\
\hline 7 & Upstream of Bahir Dar tannery & Before tannery effluent joins the river \\
\hline 8 & $\begin{array}{l}\text { Bahirdar tannery mixing point } \\
\text { Bahir Dar after mixing }\end{array}$ & When tannery effluent mix with the river \\
\hline 9 & & $200 \mathrm{~m}$ below the point of mixing \\
\hline 10 & Upstream of Habesha tannery & Reference point to Habesha tannery impact \\
\hline 11 & Mixing of habesha tannery & Mixing point effluent with river \\
\hline 12 & After mixing & $200 \mathrm{~m}$ after mixing \\
\hline
\end{tabular}

Table 2 Sampling Points with its Coordinate System

\begin{tabular}{lll}
\hline Sampling Points & Longitude & Latitude \\
\hline 1 & $37^{\circ} 24^{\prime} 28.11^{\prime \prime} \mathrm{E}$ & $11^{\circ} 36^{\prime} 23.99^{\prime \prime} \mathrm{N}$ \\
2 & $37^{\circ} 24^{\prime} 29.84^{\prime \prime} \mathrm{E}$ & $11^{\circ} 35^{\prime} 47.93^{\prime \prime} \mathrm{N}$ \\
3 & $37^{\circ} 24^{\prime} 33.42^{\prime \prime} \mathrm{E}$ & $11^{\circ} 35^{\prime} 34.55^{\prime \prime} \mathrm{N}$ \\
4 & $37^{\circ} 24^{\prime} 21.01^{\prime \prime} \mathrm{E}$ & $11^{\circ} 34^{\prime} 11.25^{\prime \prime} \mathrm{N}$ \\
5 & $37^{\circ} 24^{\prime} 18.03^{\prime \prime} \mathrm{E}$ & $11^{\circ} 34^{\prime} 6.82^{\prime \prime} \mathrm{N}$ \\
6 & $37^{\circ} 24^{\prime} 15.90^{\prime \prime} \mathrm{E}$ & $11^{\circ} 34^{\prime} 2.40^{\prime \prime} \mathrm{N}$ \\
7 & $37^{\circ} 23^{\prime} 38.60^{\prime \prime} \mathrm{E}$ & $11^{\circ} 33^{\prime} 6.05^{\prime \prime} \mathrm{N}$ \\
8 & $37^{\circ} 23^{\prime} 36.80^{\prime \prime} \mathrm{E}$ & $11^{\circ} 33^{\prime} 2.30^{\prime \prime} \mathrm{N}$ \\
9 & $37^{\circ} 23^{\prime} 36.18^{\prime \prime} \mathrm{E}$ & $11^{\circ} 33^{\prime} 0.84^{\prime \prime} \mathrm{N}$ \\
10 & $37^{\circ} 23^{\prime} 35.80^{\prime \prime} \mathrm{E}$ & $11^{\circ} 32^{\prime} 54.62^{\prime \prime} \mathrm{N}$ \\
11 & $37^{\circ} 23^{\prime} 34.31^{\prime \prime} \mathrm{E}$ & $11^{\circ} 32^{\prime} 53.27^{\prime \prime} \mathrm{N}$ \\
12 & $37^{\circ} 23^{\prime} 35.60^{\prime \prime} \mathrm{E}$ & $11^{\circ} 32^{\prime} 52.36^{\prime \prime} \mathrm{N}$ \\
\hline
\end{tabular}

Table 3 the most upstream part, point of mix and the most downstream

\begin{tabular}{llll}
\hline ID & $\mathbf{X}(\mathbf{m})$ & $\mathbf{Y}(\mathbf{m})$ & Site description \\
\hline $\mathbf{1}$ & 326539.8 & 1283514.726 & Upstream site \\
$\mathbf{2}$ & 326539.7 & 1282441.347 & Textile mixing \\
$\mathbf{3}$ & 325716.3 & 1279274.98 & Municipal ditch \\
$\mathbf{4}$ & 324871.3 & 1277789.498 & Bahir Dar Tannery \\
$\mathbf{5}$ & 324801.2 & 1277231.358 & Habesha Tannery \\
$\mathbf{6}$ & 324923.2 & 1276773.83 & Down stream \\
\hline
\end{tabular}

\subsection{Sampling and Laboratory analysis}

During the measurement of physicochemical concentration, 24 water samples from 12 sampling stations were collected in March and May 2017 (table2). Water samples were collected from the Abay River using Acid washed polyethylene bottles for chemical analysis based on standard procedures. The samples, which were collected were transported to the lab by keeping them in a cooled icebox and later stored in a refrigerator below $4{ }^{\circ} \mathrm{C}$ until use. Some of the parameters were measured on-site with the Multimeter Prob by dipping the Probe about $20 \mathrm{~cm}$ below the water surface. The physicochemical properties such as total dissolved solids (TDS), water temperature, turbidity, dissolved oxygen (DO), $\mathrm{pH}$, electrical conductivity (EC) and salinity were measured using Multimeter Prob and Biochemical Oxygen Demand (BOD), ammonia Measured and chemical oxygen demand (COD) were analyzed in this study.

\subsection{Data Analysis}

The obtained dates were analyzed by comparing and contrast the results with WHO guideline standards for surface water sources, using a graph using Microsoft word 2016. 


\section{RESULT AND DISCUSSION}

During dry seasons, water samples have been collected from the Abay River to taste Physico-chemical parameters. The essential parameters of water quality were temperature, $\mathrm{pH}$, TDS, BOD, COD, DO, turbidity, EC and salinity. Assessment of contaminated water samples is achieved by comparing the measured values of all Physico-chemical parameters with the relevant criteria recommended by the World health organization for drinking water.

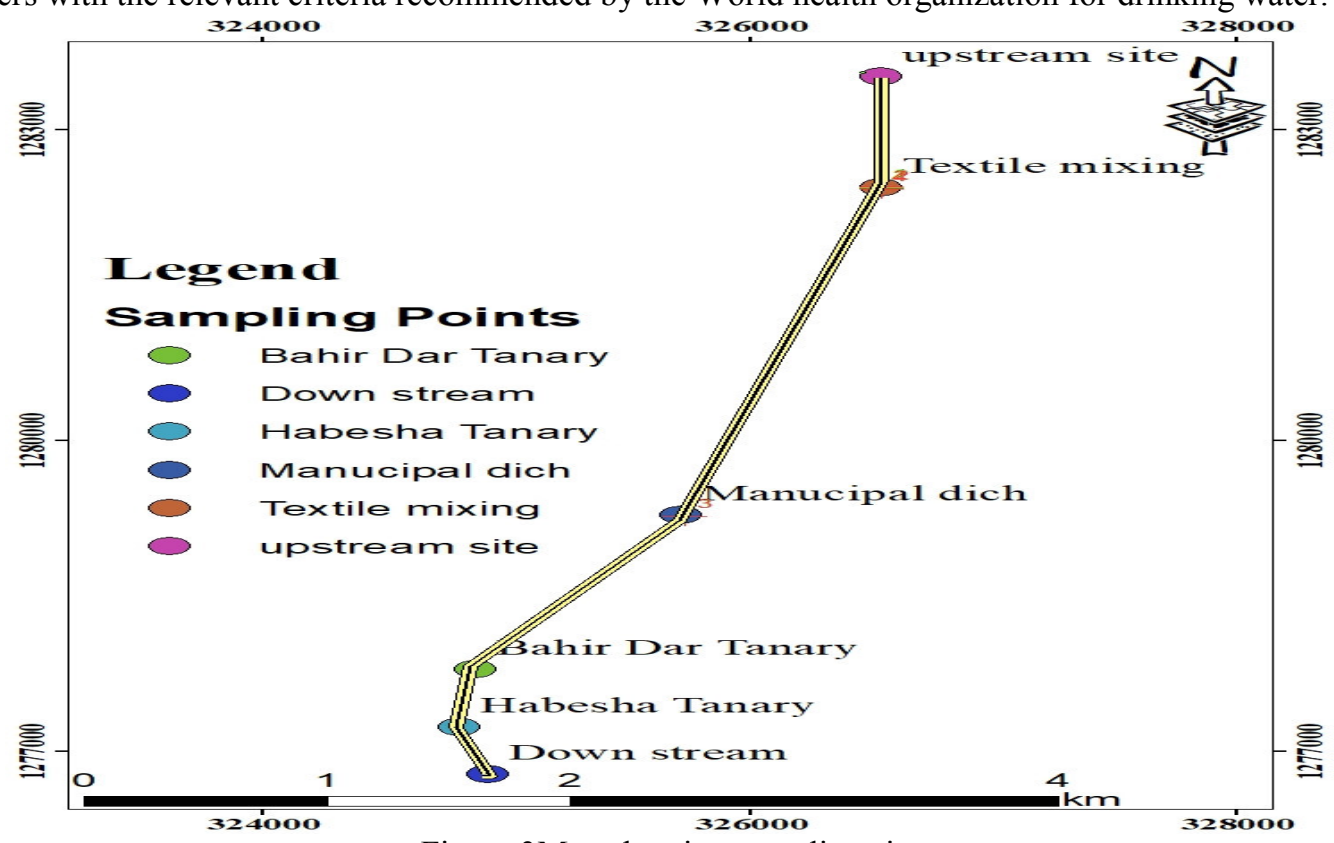

Figure 3Map showing sampling sites

Table 4 Water quality parameters versus sampling station

\begin{tabular}{ccccc}
\hline $\begin{array}{c}\text { Sampling } \\
\text { station }\end{array}$ & $\mathrm{pH}$ & $\begin{array}{c}\text { Temperature } \\
{ }^{\circ} \mathrm{C}\end{array}$ & $\begin{array}{c}\text { TDS } \\
\mathrm{mg} / \mathrm{l}\end{array}$ & $\begin{array}{c}\text { E.C } \\
\mu \mathrm{S} / \mathrm{cm}\end{array}$ \\
\hline 1 & $7.73 \pm 0.11$ & $23.5 \pm 0.6$ & $132 \pm 0.8$ & $203.08 \pm 1.3$ \\
2 & $7.8 \pm 0.08$ & $25.5 \pm 0.8$ & $247.8 \pm 2.3$ & $261.54 \pm 1.9$ \\
3 & $7.96 \pm 0.20$ & $25 \pm 0.2$ & $132.1 \pm 1.3$ & $203.23 \pm 0.3$ \\
4 & $7.4 \pm 0.16$ & $23.6 \pm 0.2$ & $157.4 \pm 2.0$ & $242.15 \pm 1.6$ \\
5 & $6.6 \pm 0.17$ & $25.2 \pm 0.0$ & $312 \pm 2.6$ & $480 \pm 0.8$ \\
6 & $7.8 \pm 0.05$ & $24.6 \pm 0.6$ & $127.1 \pm 1.3$ & $195.54 \pm 1.8$ \\
7 & $7.38 \pm 0.01$ & $23.3 \pm 0.6$ & $117 \pm 1.2$ & $180 \pm 3.7$ \\
8 & $7.3 \pm 0.08$ & $24.6 \pm 0.4$ & $176 \pm 0.8$ & $270.77 \pm 2.3$ \\
9 & $7.16 \pm 0.09$ & $23.2 \pm 0.4$ & $156 \pm 2.2$ & $240 \pm 2.1$ \\
10 & $7.96 \pm 0.03$ & $23.9 \pm 0.5$ & $294 \pm 2.6$ & $452.31 \pm 2.2$ \\
11 & $7.87 \pm 0.15$ & $26 \pm 0.8$ & $265 \pm 2.9$ & $407.69 \pm 1.8$ \\
12 & $6.5 \pm 0.14$ & $24.6 \pm 0.6$ & $130.8 \pm 2.4$ & $201.23 \pm 2.1$ \\
\hline
\end{tabular}


Table 5 Water quality parameters versus sampling station

\begin{tabular}{ccccccc}
\hline $\begin{array}{c}\text { Sampling } \\
\text { station }\end{array}$ & $\begin{array}{c}\text { Salinity } \\
\mathrm{mg} / \mathrm{l}\end{array}$ & $\begin{array}{c}\text { Ammonia } \\
\mathrm{mg} / \mathrm{l}\end{array}$ & $\begin{array}{c}\text { Turbidity } \\
\text { NTU }\end{array}$ & $\begin{array}{c}\text { BOD } \\
\mathrm{mg} / \mathrm{l}\end{array}$ & $\begin{array}{c}\text { COD } \\
\mathrm{mg} / \mathrm{l}\end{array}$ & $\begin{array}{c}\text { DO } \\
\mathrm{mg} / \mathrm{l}\end{array}$ \\
\hline 1 & $0.11 \pm 0$ & $0.13 \pm 0$ & $20.62 \pm 0.6$ & $5.3 \pm 0.2$ & $16 \pm 0.2$ & $6.8 \pm 0.3$ \\
2 & $0.11 \pm 0$ & $0.06 \pm 0$ & $31.23 \pm 0.7$ & $33 \pm 1.2$ & $99.1 \pm 1.2$ & $3.37 \pm 0.5$ \\
3 & $0.11 \pm 0$ & $0.03 \pm 0.2$ & $25.5 \pm 0.4$ & $8.2 \pm 0.1$ & $24.6 \pm 0.1$ & $5.3 \pm 0.4$ \\
4 & $0.11 \pm 0$ & $0.012 \pm 0$ & $20.39 \pm 0.4$ & $16 \pm 0.6$ & $48 \pm 0.6$ & $7.6 \pm 0.4$ \\
5 & $0.65 \pm 0.2$ & $0.02 \pm 0$ & $23.6 \pm 0.4$ & $42 \pm 0.8$ & $126 \pm 0.8$ & $2.5 \pm 0.1$ \\
6 & $0.11 \pm 0$ & $0.08 \pm 0$ & $20.5 \pm 0.8$ & $20 \pm 0.8$ & $60 \pm 0.8$ & $7.2 \pm 0.1$ \\
7 & $0.11 \pm 0$ & $0.3 \pm 0$ & $35 \pm 0.8$ & $12.6 \pm 0.2$ & $30 \pm 0.2$ & $7.8 \pm 0.1$ \\
8 & $0.11 \pm 0$ & $15 \pm 4$ & $38 \pm 2.2$ & $75 \pm 2.2$ & $225 \pm 2.2$ & $3.4 \pm 0.1$ \\
9 & $0.11 \pm 0$ & $10 \pm 1.7$ & $40 \pm 2.2$ & $50 \pm 1.2$ & $151 \pm 1.2$ & $4.1 \pm 0.1$ \\
10 & $0.9 \pm 1.2$ & $8 \pm 1.2$ & $12.72 \pm 0.2$ & $35.4 \pm 0.3$ & $106.2 \pm 0.3$ & $3.2 \pm 0.1$ \\
11 & $1.5 \pm 0.9$ & $0.18 \pm 0$ & $14.75 \pm 0.4$ & $40 \pm 0.8$ & $120 \pm 0.8$ & $3.5 \pm 0.1$ \\
12 & $0.11 \pm 0$ & $0.04 \pm 0$ & $10.45 \pm 0.6$ & $15.5 \pm 0.6$ & $46.5 \pm 0.6$ & $5 \pm 0.4$ \\
\hline
\end{tabular}

Figure 4 Water quality parameters versus sampling station

\section{Temperature and pH}

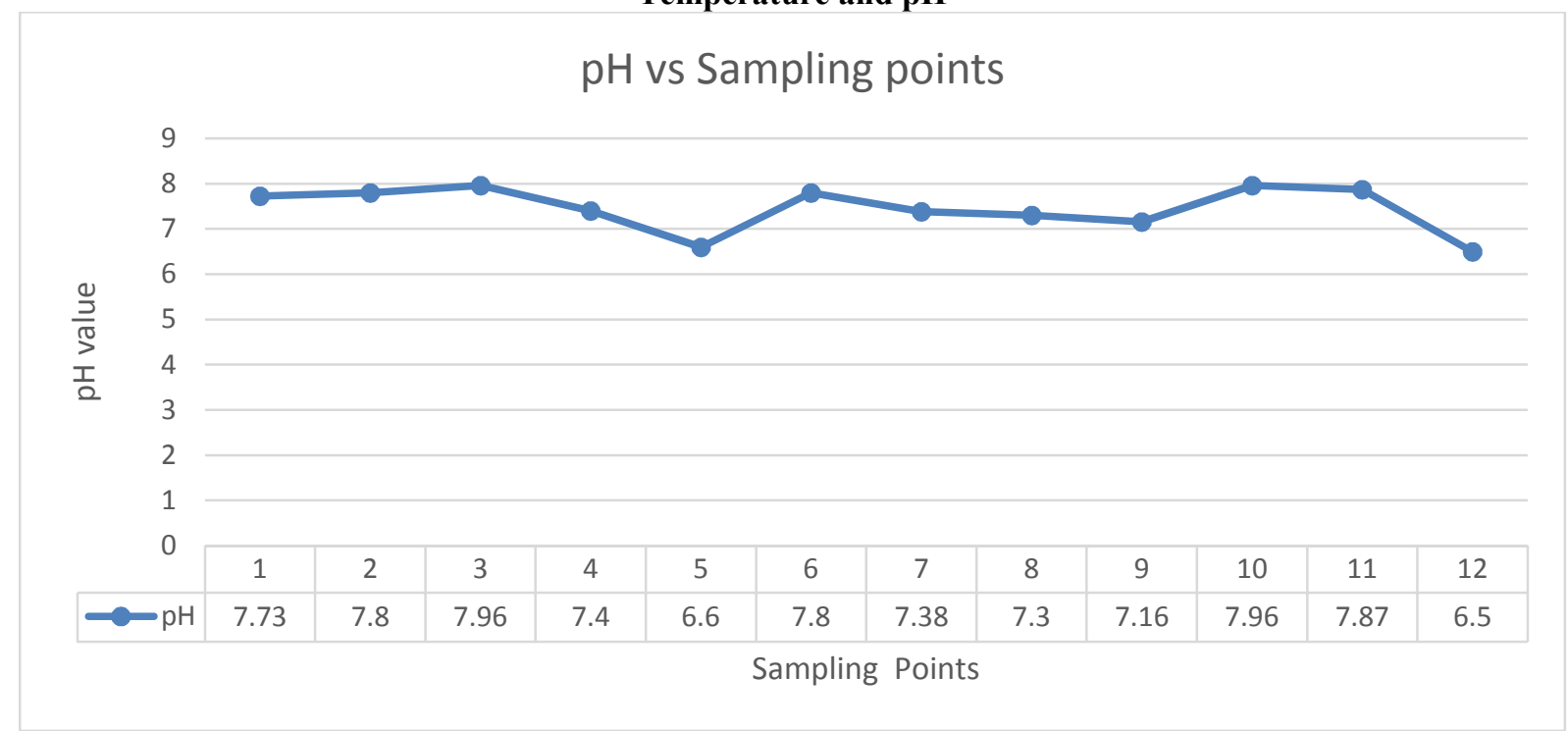

Figure $5 \mathrm{pH}$ at sampling points

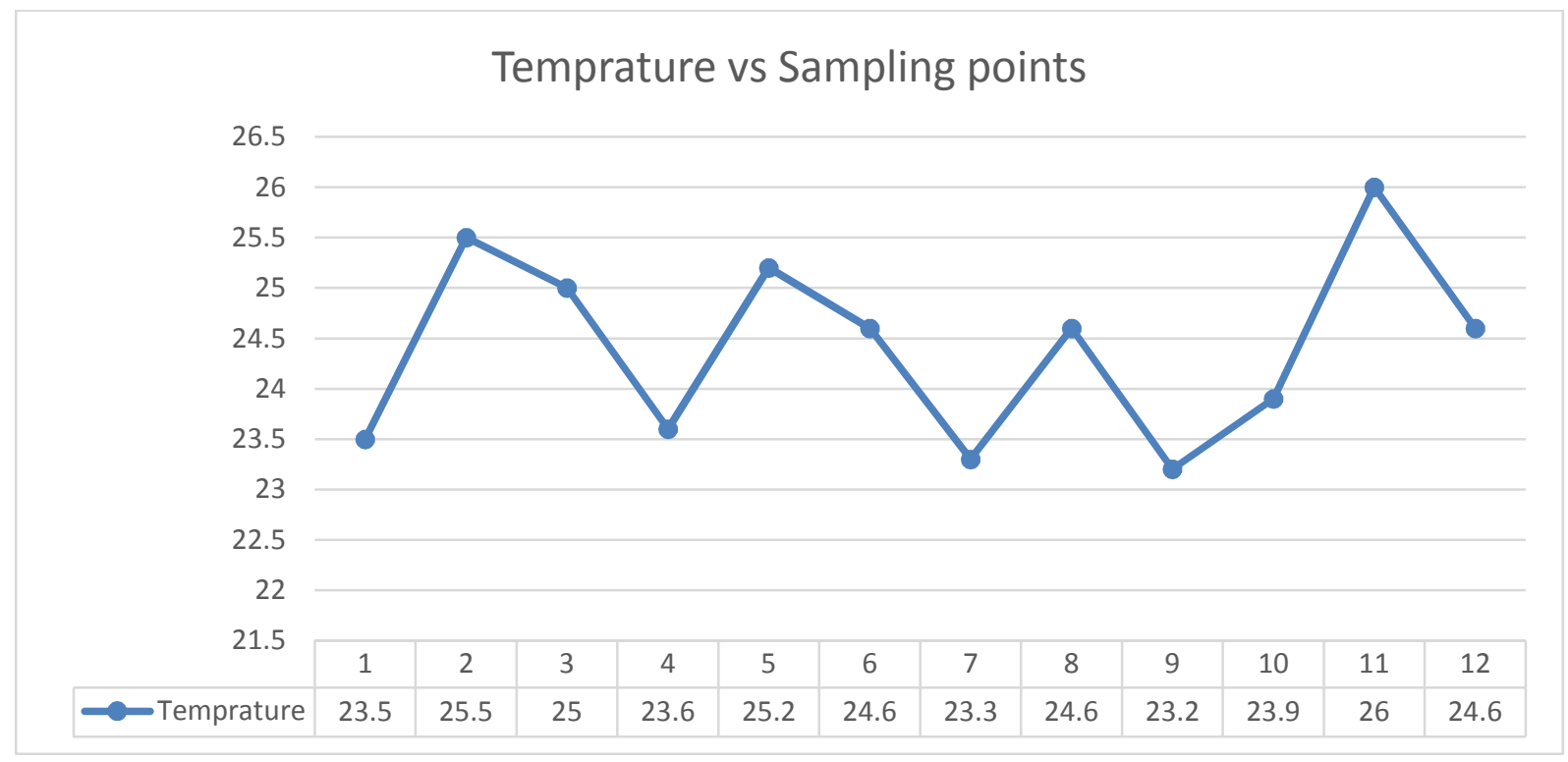

Figure 6 Temperature value at sampling points

As it is shown on figure 3 the temperature was 23.2 to $26\left({ }^{\circ} \mathrm{f}\right)$ which is within WHO and EPA limits of 25 and 
$40{ }^{\circ} \mathrm{C}$ and values of $\mathrm{pH}$ concentration of $\mathrm{pH}$ values at all sampling points was (5.5 to 7.96) was within WHO and Environmental Protection Authority (EPA) limit of 9.0.

\section{DO, BOD and COD}

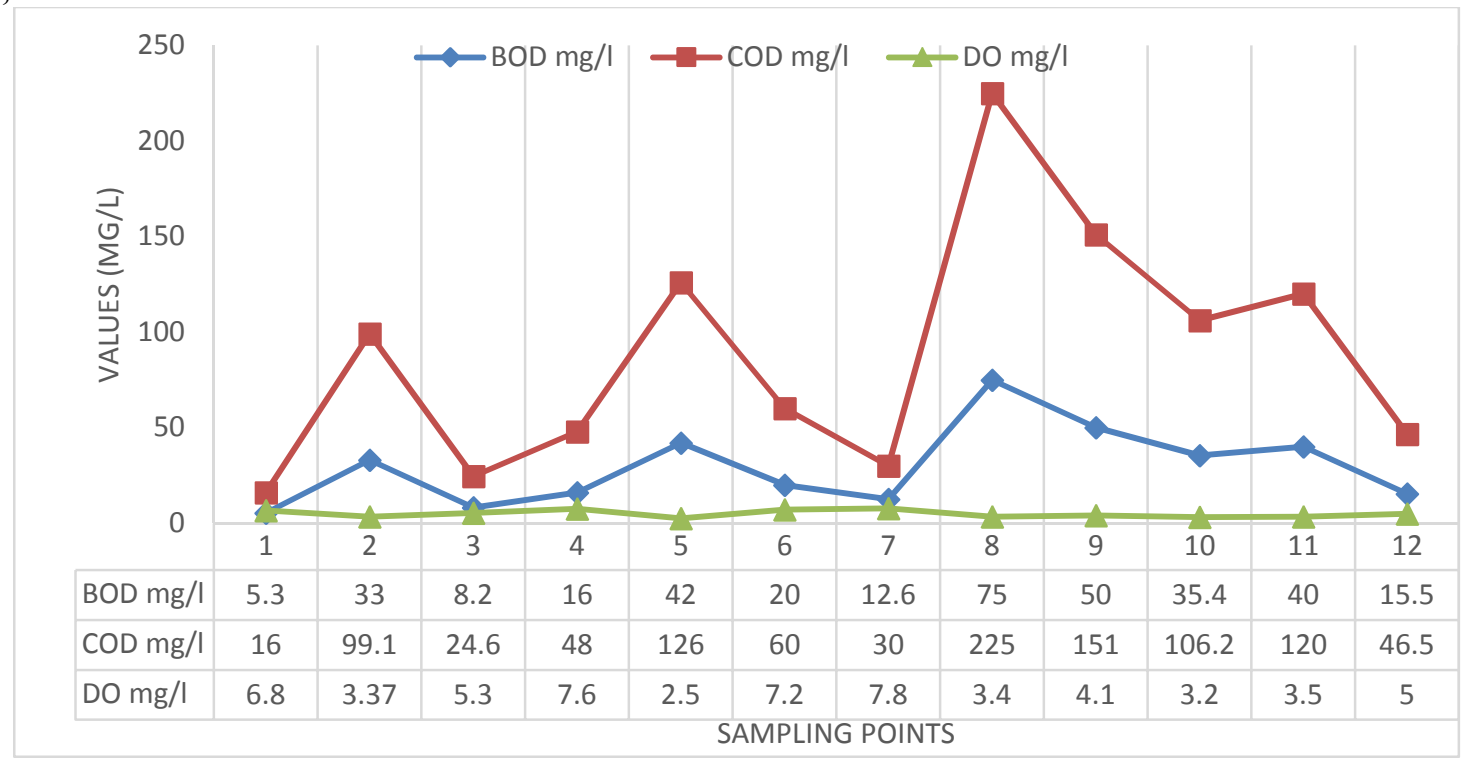

Figure 7DO, BOD and COD values at different sampling points

In the case of dissolved oxygen (DO), the maximum tolerance is $3 \mathrm{mg} / 1$ for surface waters used as raw water and swimming, and $4 \mathrm{mg} / \mathrm{L}$ for aquatic sustainability. In comparison, it is $6 \mathrm{mg} / \mathrm{L}$ for drinking purposes. The Abay River DO level ranges from 2.5 to $7.8 \mathrm{mg} / \mathrm{L}$. There water has lower DO value at all sampling points except $1,3,4,6$ and 12 than the recommended value by world health organization. Therefore, the contents do not satisfy the public water supply needs. The biochemical oxygen demand (BOD) standard for drinking purposes is $0.2 \mathrm{mg} / \mathrm{L}$, which was exceeded to the permissible value shown by the mean values of $3.88 \mathrm{mg} / \mathrm{L}$. A standard for drinking purposes is $4 \mathrm{mg} / \mathrm{L}$, which is not acceptable in terms of the Abay river water sample analyzed. The values of COD were also a standard for drinking purposes is $4 \mathrm{mg} / \mathrm{L}$, which is not acceptable in terms of the Abay river water sample analyzed.

Total dissolved solids and electrical conductivity

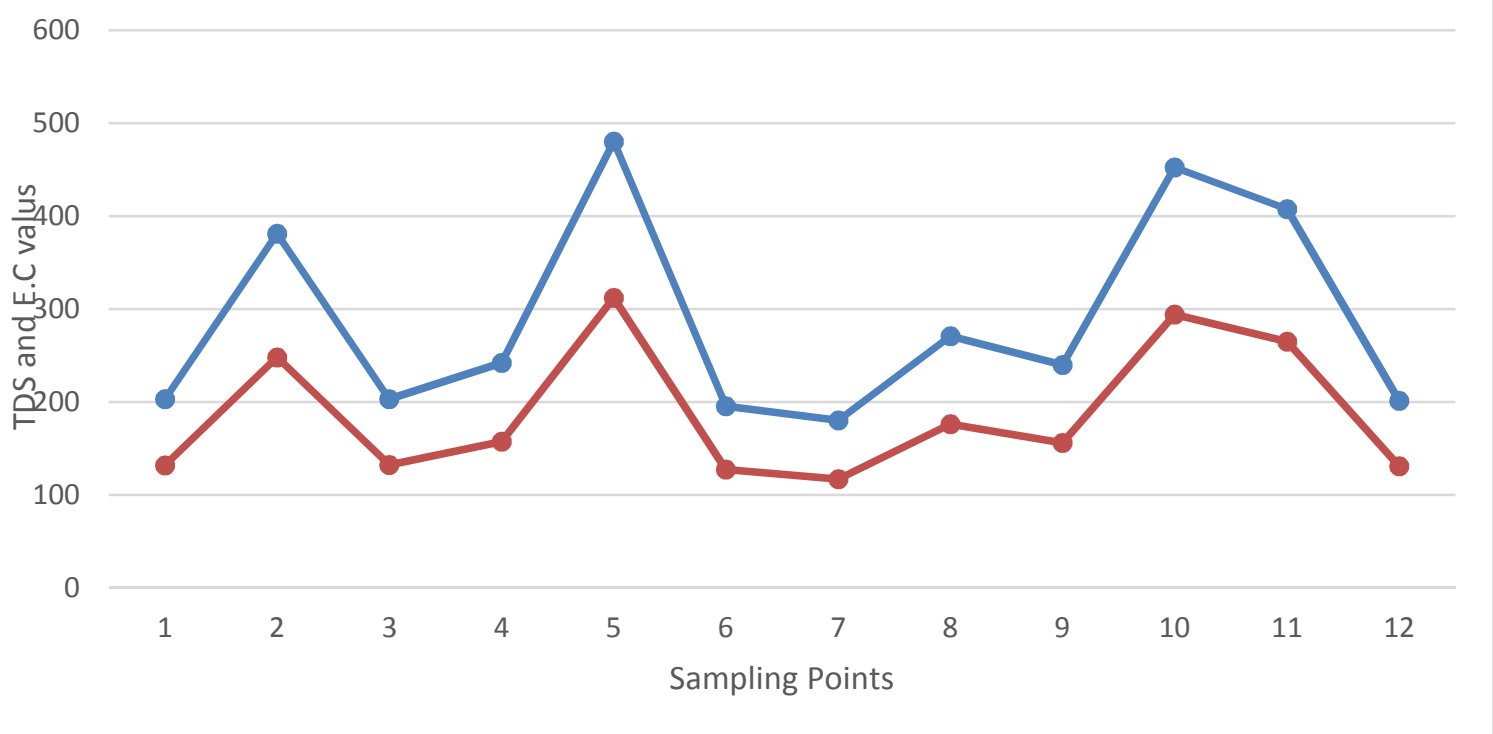

Figure 8 Total dissolved solids and electrical conductivity

The TDS content of water samples obtained at the selected stations was well below the 500mg / L WHO limit value. The allowable maximum for TDS as per WHO is $2000 \mathrm{mg} / \mathrm{L}$ in the absence of a good supply of drinking water. Increasing TDS and conductance indicates that water is unsafe to drink due to domestic and industrial wastewater discharge. The electrical conductivity value at sampling points 10 and 11 was above the permissible limit of WHO of $300 \mathrm{mg} / \mathrm{L}$. 


\section{Salinity}

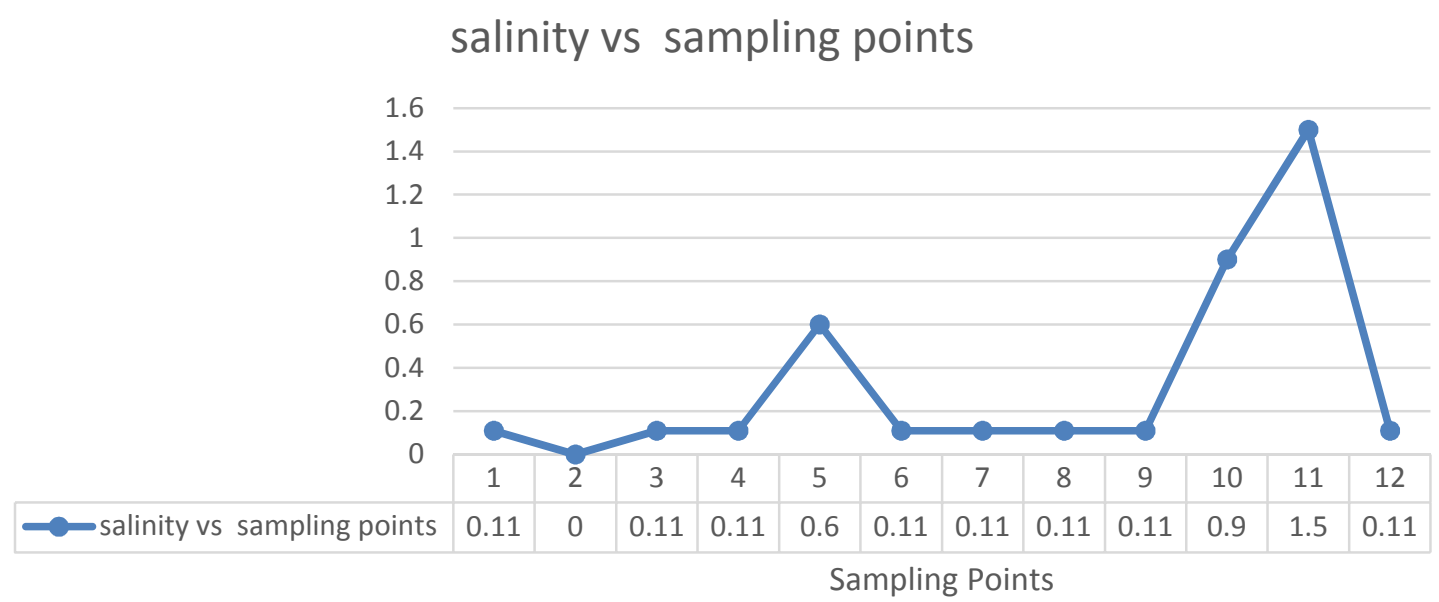

Figure 9 salinity values at sampling points

Ammonia

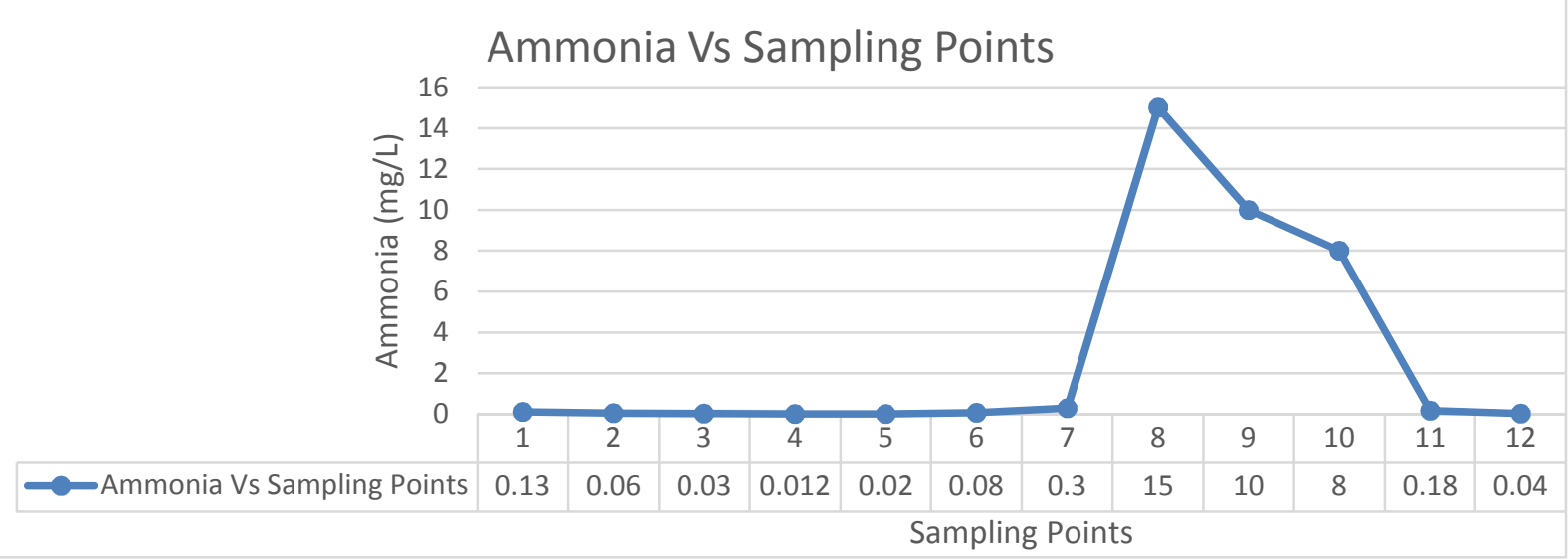

Figure 10 ammonia values at sampling points

Turbidity

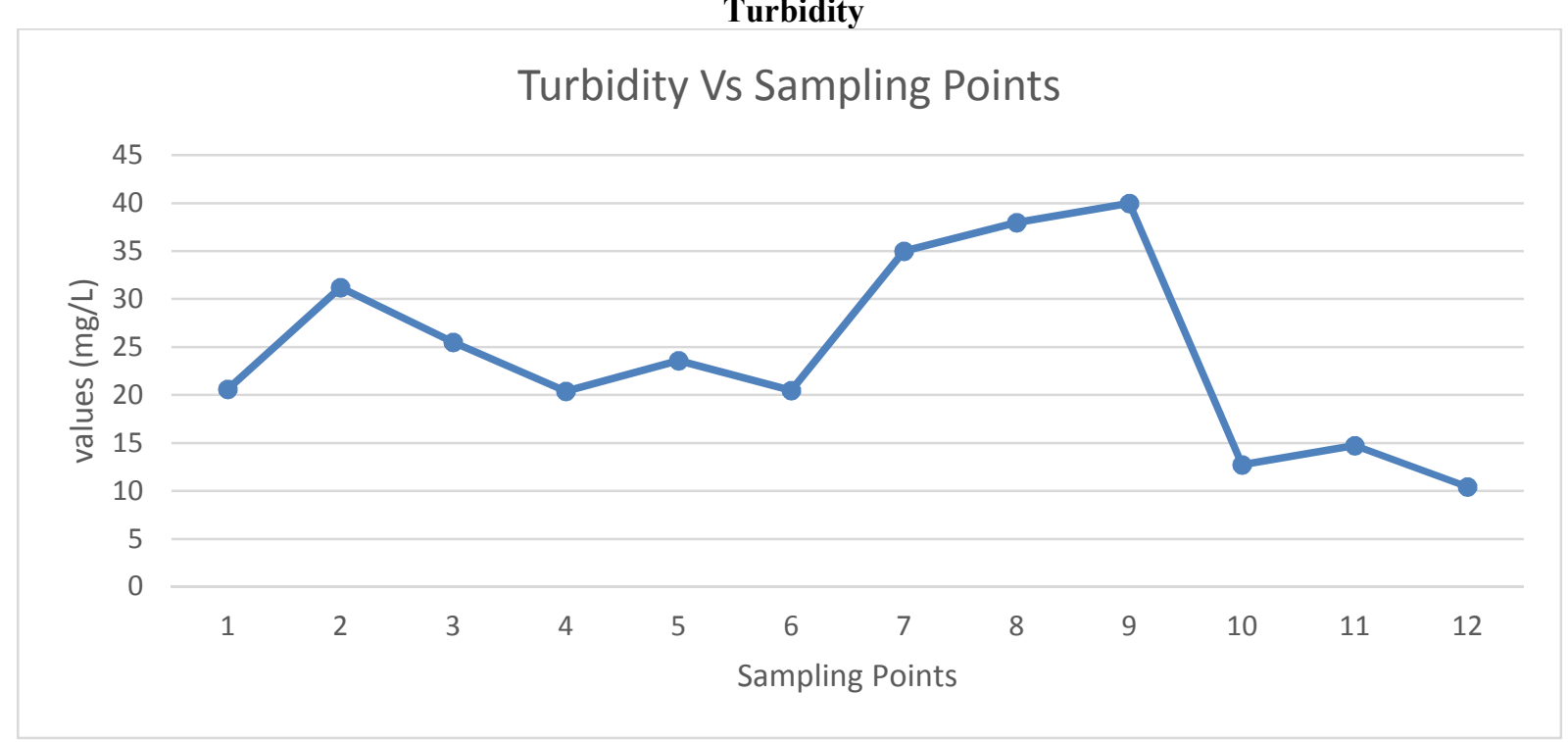

Figure 11 turbidity values at sampling points 
The mean Salinity of the Abay River was found with a range from 0.11 to $1.5 \mathrm{mg} / \mathrm{L}$. The salinity content in the Abay River was found within the EPA standard for fish $<100 \mathrm{mg} / 1$ (Thomas G. Cam 1999). The value of turbidity at all sampling points except at 2,7,8,9 all sampling points were within the WHO standard of $30 \mathrm{mg} / \mathrm{L}$. $\mathrm{NH}_{3}-\mathrm{N}$ values were less when compared with the WHO standard of $30 \mathrm{mg} / \mathrm{L}$ at all the sampling stations for surface water and EPA limit of $20 \mathrm{mg} / 1$ for surface water. The high $\mathrm{NO}_{3}-\mathrm{N}$ with the low amount of $\mathrm{NH}_{4}-\mathrm{N}$ enhanced the self-purification activities of surface water, by increasing the rate of the nitrification-de-nitrification transformation process in river water.

\section{CONCLUSION}

The data analysis results showed that the water is definitely unfit for drinking purposes without any form of treatment recommended by the World Health Organization, but it could still be considered relatively suitable for various other uses of surface water. However, as it is known, once a pollution trend sets in, it usually speeds up causing more deterioration. Increasing industrialization and urbanization over time could result in a severe deterioration in water quality. The variations in laboratory findings may be due to the experiment preservation methodology followed by laboratories, the nature of chemicals used, the test method applied or the technicians or test performers ' training or expertise. For the management of freshwater sources, continuous monitoring of the monitoring of water quality across all seasons over a period of time is important. Therefore, more work on this river and alerting the population to the environmental pollution issue is also an important need.

\section{Availability of data}

The following data, models, or code generated or used during the study are available in a repository or online. [Select Point source identification (http://dx.doi.org/10.4314/ejesm.v9i2.7). The following data, models, or code used during the study were provided by a third party (some WHO guide lines or standards for different parameters) direct requests for these materials may be made to the provider as indicated in the"Acknowledgments. The following data, models, or code generated or used during the study are proprietary or confidential in nature and may only be provided with restrictions (Sample result taken at different points specially habesha tannery effluent and soon) All data, models, and code generated or used during the study appear in the submitted article.

\section{Acknowledgment}

First and foremost, we would like to thanks our Almighty God, and his mother saints marry for all who helps us and being with us throughout our endeavor. In the second rank we would like to thank Debre Tabor University and Dimma town water office for giving as the opportunity to learn and financial support. We would like to thank the staff members of Faculty of Civil and Hydraulics Engineering at Bahir Dar Institute of Technology, Bahir Dar University for kindly good support. We are grateful for help from Ms. Lidiya Taddesse for providing a pleasant working environment during our work in the Blue Nile water institute laboratory, and for their impressive kindness and support. I shall extend my thanks to Amhara Design and Supervision Works Enterprise and Amhara Water Development office technical laboratory assistance, for all the kindness and help. I would like to thank also to Bahir Dar textile employees (especially Mr. Sileshi) that helped us during Data collection and to their willingness to take samples and to use their lab to test some parameters. We were wondering because of their interest to create a good environment for researchers and they are happy to work with educated people.

\section{REFERENCES}

Akkaraboyina, M. K. and B. Raju (2012). "A Comparative study of water quality indices of River Godavari." International Journal of Engineering Research and Development 2(3): 29-34.

Ayalew, W. A. a. W. and (2014). "Assessment of downstream impact of Bahir Dar tannery effluent on the head of Blue Nile River using macroinvertebrates as bioindicators." International Journal of Biodiversity and Conservation 6(4): 342-350.

Dudgeon, D., A. H. Arthington, M. O. Gessner, Z.-I. Kawabata, D. J. Knowler, C. Lévêque, R. J. Naiman, A.-H. Prieur-Richard, D. Soto and M. L. Stiassny (2006). "Freshwater biodiversity: importance, threats, status and conservation challenges." Biological reviews 81(2): 163-182.

Fan, C., W.-S. Wang, K. F.-R. Liu and T.-M. Yang (2012). "Sensitivity analysis and water quality modeling of a tidal river using a modified streeter-phelps equation with HEC-RAS-calculated hydraulic characteristics." Environmental Modeling \& Assessment 17(6): 639-651.

Haider, H., W. Al and S. Haydar (2016). "A review of dissolved oxygen and biochemical oxygen demand models for large rivers." Pakistan Journal of Engineering and Applied Sciences.

Mahananda, H., M. Mahananda and B. Mohanty (2005). "Studies on the physico-chemical and biological parameters of a fresh water pond ecosystem as an indicator of water pollution." Ecology environment and conservation 11(3/4): 537.

Mahananda, M., B. Mohanty and N. Behera (2010). "Physico-chemical analysis of surface and ground water of Bargarh District, Orissa, India." International journal of research and reviews in applied sciences 2(3): 284295. 
Mehari, A. K., S. Gebremedhin and B. Ayele (2015). "Effects of bahir dar textile factory effluents on the water quality of the head waters of Blue Nile River, Ethiopia." International journal of analytical chemistry 2015.

Mehari, A. K., S. Gebremedhin and B. Ayele (2016). "Effect of Bahir Dar municipal effluents on water quality of the head of Blue Nile River." Ethiopian Journal of Environmental Studies and Management 9(2): 197-208.

Miller, J. R. (2005). "Biodiversity conservation and the extinction of experience." Trends in ecology \& evolution 20(8): 430-434.

Sahoo, M. M. (2014). Analysis and modelling of surface water quality in river basins.

Stålnacke, P., A. Grimvall, C. Libiseller, M. Laznik and I. Kokorite (2003). "Trends in nutrient concentrations in Latvian rivers and the response to the dramatic change in agriculture." Journal of Hydrology 283(1-4): 184205.

Tamiru, A., L. Dagnachew, A. Tenalem, T. Yirga, W. Solomon and M. Nuri (2004). "Assessment of pollution status and groundwater vulnerability mapping of the Addis Ababa water supply aquifers." Ethiopia.(available online at http://www. unep. org/groundwater project/Countries/Ethiopia/Report/Nov2004. pdf)(unpublished).

Thillai Arasu, P., S. Hema and M. Neelakantan (2007). "Physico-chemical analysis of Tamirabarani river water in South India." Indian Journal of Science and Technology 1(2): 1-5.

Thomas G. Cam, P. H. E., J. David Holm,and Thomas C. Turney (1999). "Review of water quality standards for salinity COLORADO River system." 